\title{
Ethnoecology of Mentawai on Utilization of Plants in Conservation Biodiversity in Siberut, West Sumatra
}

\author{
Fatimah Fatimah ${ }^{1 *}$ Nisyawati $^{2}$ \\ ${ }^{1}$ Biology Department, Mathematics and Sciences Faculty, Indonesia University, Jakarta, Indonesia \\ ${ }^{2}$ Biology Education Department, Teacher Training and Education Mathematics and Sciences Faculty, Indonesia \\ University Jakarta, Indonesia \\ *Corresponding author.fatimahjannnah9@gmail.com
}

\begin{abstract}
Mentawai archipelago separated from Sumatra milions years ago. The utilization and management of landscape units of the Mentawai community in siberut, is strategies to maintain their survival. A large sea barrier promotes biodiversity differ from other areas include flora and fauna endemic. The observation was implemented to analyzing utilize of management landscape units and managing conservation biodiversity by local wisdom. The survey sites were in the villages of Bekemen, Sikabaluan and Sotboyak North Siberut, Mentawai Islands Regency, West Sumatra Province, Indonesia. We conducted the study from AugustSeptember 2019. Data were collected by observation, interview and literature study. The results showed the local community of North siberut divided the landscape into the 7 units, leleu (hutan), pumonean (agroforest), pusaguat (sago), pugettekat (taro), puberakat (rice fields), barasi (villages) and bat oinan (rivers). The composition of landscapes divided according to the local knowledge and the main sources of livelihood is in the field and forest. Land use in Mentawai islands has their own right of ground by some of Mentawai tribes. Traditional land use strategy by local community passed down from generation to generation and it we expected to maintain the diversity that exist in the landscape.
\end{abstract}

Keywords: conservation biodiversity, mentawai community, traditional land use, unit landscape.

\section{INTRODUCTION}

Mentawai Islands is one of the islands, which is isolated from the plate Sundanese found in Indonesia, since the Pleistocene has been isolated approximately 500,000 million years ago. The islands are located approximately 85 to $135 \mathrm{~km}$ from the coast West Sumatra. Mentawai has four islands namely Siberut, Sipora, North Pagai and South Pagai. Among these four islands, Siberut is the largest island with an area of 4,030 km and the smallest island is Sipora with an area of $845 \mathrm{~km} \mathrm{2}$. This archipelago has rainfall annual high rainfall of 4,400 $\mathrm{mm}$ (Tenaza, R., 1987; Tilson, R.L, 1980). The Mentawai river valley has been isolated from the main island of Sumatra as deep as 1,500 m (Batchelor, B.C., 1979; Dring et.al, 1990). Isolation of the island has occurred on this island since millions of years ago making this island has a high endemicity on existing biodiversity. The Mentawai community as a whole still utilizes natural resources or biodiversity that exists both on land and in the ocean. In this case, the community assumed to have traditional ecological knowledge (Darmanto, 2011). One of biological source that has widely used by humans since long are plants. Plants are also the basis life on earth and human livelihood. Human interaction with plants so important, studying plant knowledge has arisen throughout history humans on earth (Hakim, 2014). In one Mentawai ethnic group, it is usually chaired by the head namely sekerei.
Sekerei states that an important part of his existence depends on the natural surroundings especially biodiversity (Zamzami, L. 2013). Biodiversity of both plants and animals used by the community as sources of clothing, housing, food, money income, ceremonies and culture that proclaimed from the forest. This can be seen through the daily life of Mentawai people who are farming planting and hunting animals. The Mentawai people grow crops and make use of the results forests exist for various needs. Apart from that, forests also used as one learning objects that passed down from parents to children which are, expected to protect and protect the forest in the future. Mentawai people in practice now have a lot changes in both the state of nature and society have begun to adapt to modern environment. The state of nature is the extent of the forest decreases in size, plants and animals that are increasingly difficult to find (Zamzami, L. 2013). Therefore, it is very necessary studies ethnoecology of the Mentawai people in supporting theexistence of biodiversity, nurturing people's knowledge and daily activities. Apart from that it can be expected in helping to conserve biodiversity and increase efforts community awareness in the management of biodiversity.

\section{MATERIAL AND METHODS}

The study was conducted from August to September on Siberut communities in tree villages: Bekemen, Sikabaluan 
and Sotboyak North Siberut, Mentawai Islands Regency, West Sumatra Province, Indonesia. The Villages was selected by purposively sampling from from the village close to the estuary to the village closest to the forest was made a National Park Siberut by the Government. Bekemen located in the core area, sotboyak in the center of area and Sikabaluan is near from the estuary. This study is used a qualitative approach. Data were Data were collected by observation, interview and literature study. Study of literature by collecting publication data relating to the natural resources of the Mentawai community and the diversity that exists in Mentawai. Interviews with 27 informants were selected based on their knowledge and experience of traditions, natural resources used and biodiversity in each landscape. Direct observation to community land and forests that exist in Siberut. The process of data analysis is done through the process of grouping, coding and interpreted data for the conclusion.

\section{RESULT AND DISCUSSION}

Forests in the Mentawai community in the North Siberut area referred to as leleu. The community uses the forest to collect timber and non-timber forest products. The forest wood product used by the community for building materials in the uma (traditional house) of the Mentawai community and for making pompong (sampans). The wood used for making uma and sampan is from the genus Dipterocarpacea and the genusShorea. Besides the use of wood used as firewood for cooking.

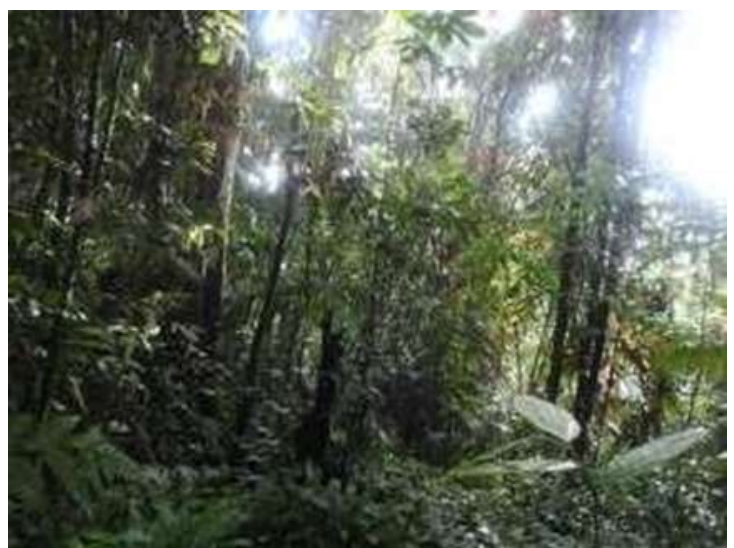

Fig. 2. Forest in Bekemen, North Siberut

The survey results shows, there were 18 types of trees used for building materials, 3 types of canoes making trees. Trees in the forest besides used by humans also used in endemic primates in the Mentawai islands, including Presbytis siberu, Simias concolor, Hylobates klosii and Macaca siberu. At the time of the survey, we found one of the primates, namely Simias concolor which isin the Dipterocarpacea tree. Non-timber forest products obtained are from the genus Musa, honey, medicinal plants and manau (rattan). In North Siberut, Honey has been trade.
Nopiansyah F., 2017 Mentawai people depend their lives on forests and fields.

Pumonean or Argoforest Fields in Mentawai. Most of the Mentawai communities own fields, interview data from 27 informants on average all have fields both working in government and ordinary people. Mentawai has a mixed cultivation system due to ownership rights in every tribe in Mentawai. The informant stated that it was very difficult to make land acquisition and become a monoculture field because only the usage rights permitted by the existing tribes not as ownership rights, so that the existing plants could not be disturbed, except for the tribal lands themselves which werecultivated.

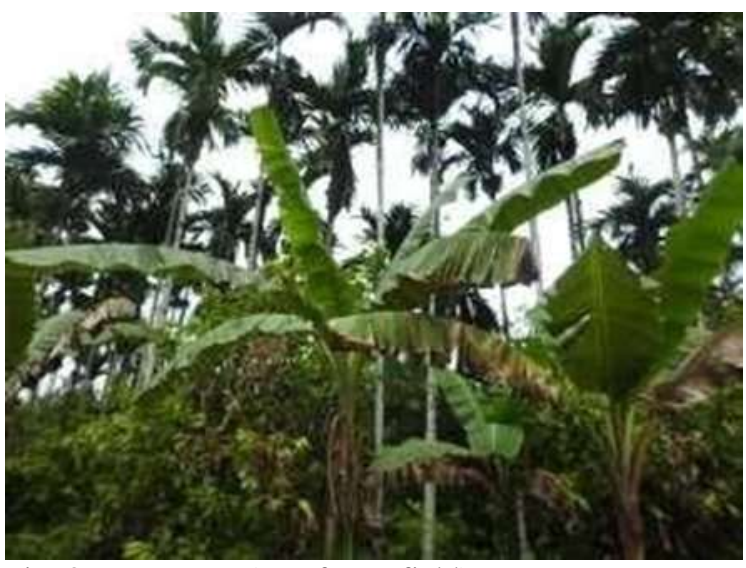

Fig. 3. Pumonean (agroforest field)

The concept of use rights can be seen from the ownership of village land which inhabited by many uma, as well as the location of the fields and forests that are becoming the back of life of the community, whose land is only owned by a few uma (Nopiansyah F., 2017).

The types of plants that were obtained during the survey were Musa spp. (Banana), Theobroma cacao (chocolate), Arenga pinanga (Pinang), Cocos nucifera (toitot), Colocasia esculenta (taro), Eugenia aromatica (clove), Ipomea batatas (cassava), Durio zibhetinus (Duriat), Psidium guajava (jambu), Cinnamomum zeylanicum (cinnamon) and Arthocarpus heterophylus(peigu/jackfriluit).

The plants planted by the community aside from eaten daily, are tradional and traded medicines. Interviews conducted by informants stated that those with high selling points were banana, pinang, manau, coconut and chocolate. Febrianto and Fitriani (2012) that people Mentawai fulfill their daily needs from farming. Most plants cultivated is a native plant that comes from the forest. This indicates pumonean bringing together economic and ecologicalinterests.

Pusaguat (sago) is a staple food for the Mentawai community. Sago (Metroxylon sagu) planted in swamps. Lowland chosento plant sago because it is more fertile than the highlands. Sago has many benefits for the community, namely leaves used as a wrap of kapurut food. Starch extract is processed into sago flour is processed by 
the community as daily food; bark is used as a wall for making sago processinghuts.

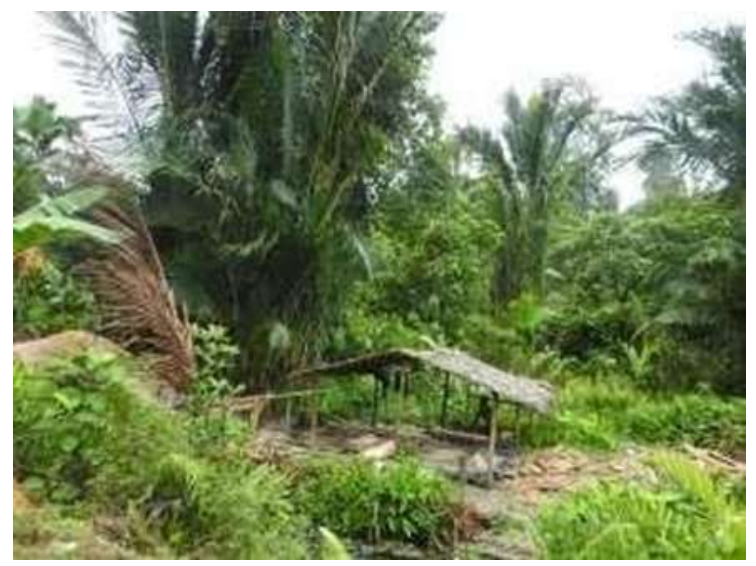

Fig. 4. Pusaguat (Metroxylon sagu)

Each sago stem with a length of $20 \mathrm{~m}$ can produce flour around $600 \mathrm{~kg}$ (10 pieces). Each tampin can meet the needs of one family small (4 people) for 10 days, in other words one can sago sticks support a family for about 3 months. In one year, one family only need about five sago stems (Susanto, 1994). Processing traditional sago from cutting down to flour requires time is around 30 days with 8 hours work hours per day (WWF 1980). At present there is already a sago flour-producing machine placed in several villages, one of which is the village of Sotboyak so it takes less time.

Pugettekat (taro) taro fields are the second staple food source for the community. Pugetekat is made around settlements that are cultivated in watery environments such as on river banks or near ditches.

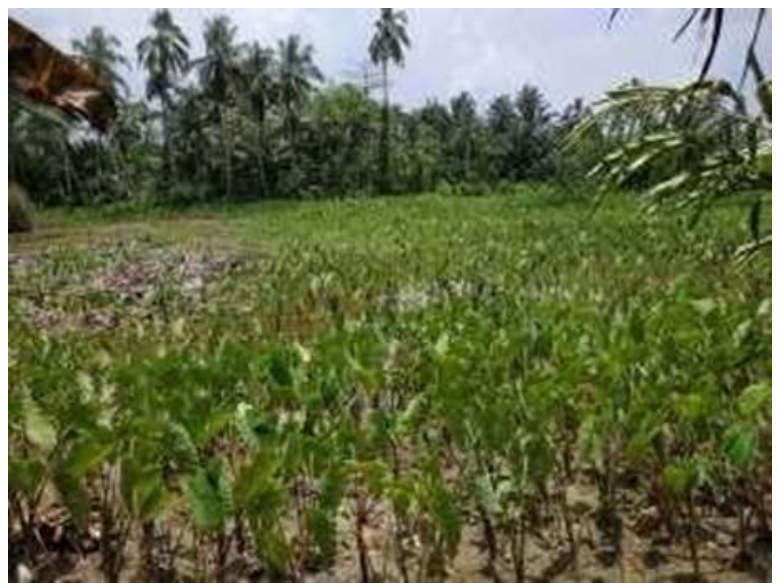

Fig. 5. Pugettekat (Colocasia esculenta)

Nopiansyah F. (2017) Taro became the main food source other than sago. Besides that, taro important because it can be a medium of exchange, such as to pay debts, dowry, fine, orsold.

Puberakat (rice fields), is a term used by the Mentawai community to refer to the rice field landscape. North Siberut rice fields are found in two villages namely in
Malancan and Sotboyak villages. The informant explained that the rice field developed in the village was a program to build rice fields on Siberut Island as part of the District Government's program in order to eliminate the rice program for the poor (raskin). Malancan and Sotboyak villages open 50 ha of paddy fields.

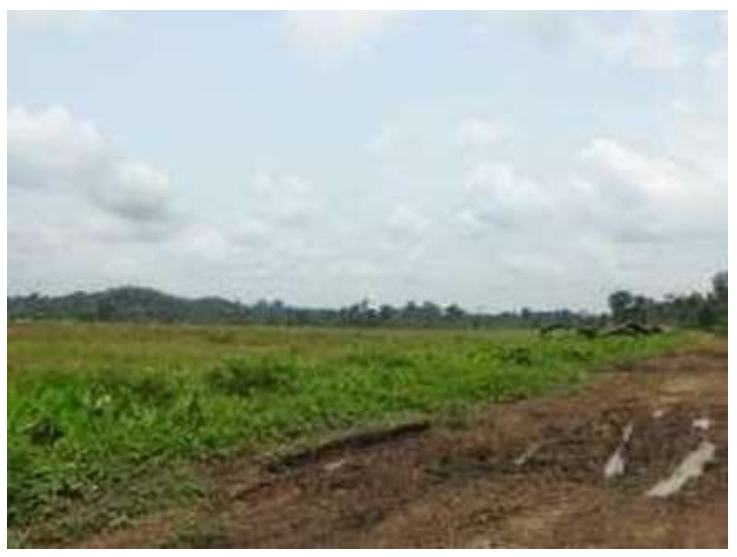

Fig. 6. Puberakat (rice fields)

To ensure food security, the agriculture service conducts a land clearing program rice fields so that people can consume rice and not depend on rice supplies from outside Mentawai (Simanjuntak2012).

Barasi (villages) Settlements in the Mentawai community called barasi. Settlements in these villages have structured spatial planning. The building materials used to construct buildings come from natural resources in the forest. The types of plants used were koka (Dipterocarpus sp.), Boklo (Shorea sp.), Sipuai lompa (Eugenia sp.), Sipubere (Artocarpus haseltii) and karai (Hopea sp.).

Mentawai people have the prerequisites formaking a location as a traditional settlement (Hernawati 2007), namely: 1. available water sources (tributaries/ batsopak) around the prospective settlement location. 2. Available land / flat land (su's) with an area that is sufficient for the locationestablishingsapou (a house inhabited by one family) for sipuuma. 3. no flood-prone, some distance from the big river.

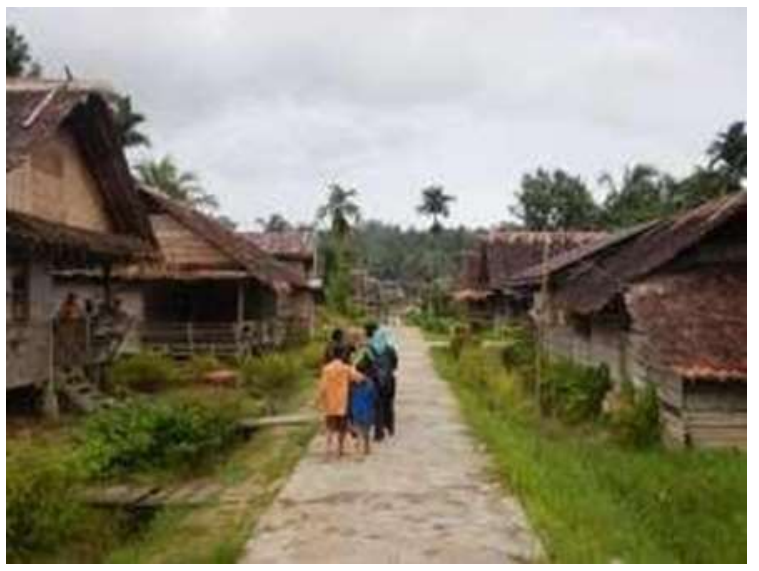

Fig. 7. Barasi (settlement) 
4. adjacent, to swampy areas (onaja) as a location for sago farming and taro farming as well as ponds fish. 5. adjacent to forested areas (leleu) for farming, searching medicinal plants, and hunting. 6. Land, has a history with the life of the grandmother the ancestors of the uma member (pangubuat), for example a former farm, a former place hunting, or the location of their common ancestors. Next, settlement this is generally located on uma ownedland.

Bat oinan (rivers) Mentawai people use the river as a means of transportation. Thevillages has a road but the community uses the river more as a means of transportation. This is because rivers are more effective for traveling between distant villages and carrying agricultural produce.

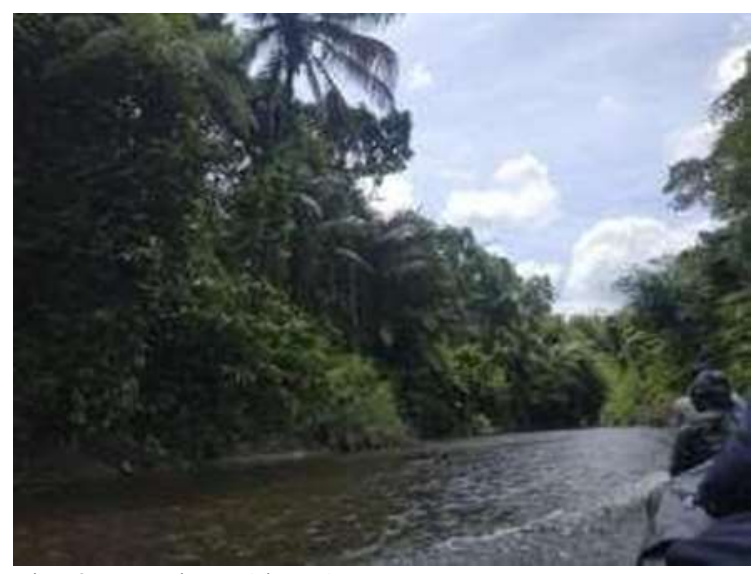

Fig. 8. Bat oinan (rivers)

Mentawai community is very dependent on the river can be seen in the arrangement of residential spaces close to the river flow. In addition, the river ecosystem also used by the community to look for fish, shellfish and shrimp.

\section{CONCLUSION}

The local community of North siberut divided the landscape into the 7 units, leleu (hutan), pumonean (agroforest), pusaguat (sago), pugettekat (taro), puberakat (rice fields), barasi (villages) and bat oinan (rivers). The distribution adjusted to the carrying capacity of the landscape in meeting the socio- cultural and economic needs of the community. Distribution of existing landscapes such as mixed fields supports diversity and conservation actions for flora and fauna.

\section{REFERENCES}

[1] Batchelor, B.C. 1979. Discontinously rising late Coenozoic eustatic sea-levels, with special reference to sundaland, Southeast Asia.Geologia en Mijnbouw 58:1-20.

[2] Dring, J.C.M., McCharthy C. M., Whitten A.J., 1990. The tersterial herpetofauna of the Mentawai Islands, Indonesia. Indo- Malayan Zoologi. 6:119-132.
[3] Darmanto. 2011. konservasi global taman nasional siberut dan praktek lokal di pulau Siberut, Sumatera Barat. Ilmu Kehutanan. (V) 1: 51-65.

[4] Febrianto A, Fitriani E. 2012. Orang Mentawai: Peladang tradisional dan ekonomi pasar. Humanus. 11(2):119-133.

[5] Hernawati TS. 2007. Uma: Fenomena Keterkaitan Manusia dengan Alam. Padang (ID): Yayasan Citra Mandiri. $\mathrm{x}+110 \mathrm{hlm}$.

[6] Hakim. 2014. Etnobotani dan manajemen kebunpekarangan rumah: ketahanan pangan, kesehatan dan agrowisata. Penerbit selaras perum, Malang: vii+280 hlm.

[7] Nopiansyah F. 2017. Penguatan Kelembagaan Lokal Pengelolaan Sumber Daya Alam Sumber Penghidupan Suku Mentawai Di Cagar Biosfer Pulau Siberut [disertasi]. Bogor (ID): Institut Pertanian Bogor.

[8] Simanjuntak PT. 2012. Pergeseran Makanan Pokok Terhadap Perluasan Cetak Sawahdi Mentawai [internet]. Padang (ID): Puligoubat.

[9] Susanto H. 1994. Pembangunan Pulau Siberut:

[10]Catatan Alternatif Pengembangan. Masyarakat Indonesia.20(4):71-92.

[11]Tenaza, R. 1987. The status of primates and their habitats in the Pagai Islands, Indonesia. Primate Conservation. (8):104-110.

[12]Tilson, R.L. 1980. Monogamous mating systems of gibbons and langurs in the Mentawai Islands, Indonesia. $\mathrm{PhD}$ thesis, university of California, Davis.

[13]WWF] World Wildlife Fund. 1980. Penyelamatan Siberut: Sebuah Rancangan Induk Konservasi. Bogor (ID): WWF.

[14] Zamzami, L. 2013. Sekerei Mentawai: Keseharian dan tradisi pengetahuan local yang digerus oleh zaman. Antropologi Indonesia. (34) 1: $29-40$. 